into the substance of the brain. In roung just hatched I never found any. In young from two to three weeks old I found them in their stomachs and the alimentary canal. When about ready to fly I found coiled perhaps two or three on the brain."

Further on in his note to me he say6: "I was surprised to learn of your finding them in Boturus-but I should not have been for I consider them primarily a fish parasite and developed from the eggs taken with the fish into the stomach of the bird, and hence like Trichina spirulis finding their way to the brain."

Professor Jenks called my attention to a note he published on this find in his " Popular Zoology," but which I had overlooked. He also gare me the address of Dr. W. Cahall of Philadelphia who had published an article on the subject, based largely on the material Professor Jenks obtained from Florida There is only one point in Dr. Cahall's article (Journal of Nervous and Mental Diseases for June, 1889), that I wish to speak of, and that is that while 19 out of 20 Snake Birds have these brain parasites they do not seem to affect them unfarorably. This was not the case with the Bittern. It was poor in flesh, of inferior size and deficient in intelligence.

That birds do get parasites from fish I might add the following case of circumstancial evidence: When skinning. a perch (Perca flavescens), I found in the muscles a number of encysted parasites, the cysts white and about an eighth of an inch long A short time afterwards in skinning a wild duck I found a similar if not the same parasite in the pectoral muscles. The two parasites were of the same size and color and seemed to be the same.

G. H. French.

Carbondale, I!1.

\section{The International Botanical Congress at Madison.}

In looking over the "Circular and General Programme of the Forty-Second Meeting of the American Association for the Advancement of Science" just distributed, I am surprised to read on page 12, under the heading "International Botanical Congress," the following statement: "The congress will consider questions of general botanical interest, but papers embodying the results of research $\mathrm{w}$ ill be excluded. The International Standing Committee upon Nomenclature, appointed last year at the Genoa Congress, is expected to present a report at this time." This is all that is said in the circular to indicate what we may expect to hear at the Congress.

The Botanical Gazette, in an editorial, ${ }^{1}$ urges "If any botanist has a suggestion ... now is the time to give it expression. . . . Silence means apathy." I fear a certain class of our botanists hare been silent too long, judging from the above statement. It seems to me outrageous to announce a programme from which all original research is excluded. No scientific man cares to listen to papers which are merely "a play of words," not the results of research. I should consider it an insult to our foreign guests to offer such a programme. The one subject suggested, nomenclature, is indeed about the only one possible under such restrictions, being truly void of all scientific reseasch.

Botanical congresses do not come every year, especially in America, this being the first erer held here, if $I$ am rightly informed. This being the case, it seems to me, as a matter of course, that this should be the time and place for a discussion of the vital questions of physiology, morphology, anatomy, etc., that this should be the time for an extreme effort on the part of every American botanist. If we desire to gain standing as true botanists among the true botanists abroad, our supreme effort should be directed to botany, not as appears to be the intention, to a mere machine of botany. It would $\mathrm{s} \in \mathrm{em}$ a better restriction if all papers not the result of research were excluded.

Papers from America have long presented this characteristic no "result of research." Nomenclature and floristic is truly all that we have thus far accomplished. One is, unfortunately, compelled to believe that "Free Lance", ${ }_{2}$ accidentally omitted to include botany when he said: "The Entomological Society is

\footnotetext{
${ }^{1}$ Botanical Gazette, vol, xvil. (November, 1892), p. 384. p. 25 .
}

recruited very largely from the ranks of 'collectors' who notoriously infest entomology far more than any other branch of natural history." The omission is at least unfortunate. The following sentences of the paragraph are so pithy and to the point that I cannot refrain from quoting them also: "The great majority of these have probably no interest in science generally, but care only for those things relevant to butterfly collections (herbaria, in our case). They would never become Fellows of the Linnæan, and care chiefly to discuis 'collectors' topics, that would be quite out of place in that society; so that the Entomological Society affords them a sort purgatorial limbo, midway between the paradise of science and the inferno of popular nescience."

I trust that I missunderstand the word research as used by the committee, but it would seem desirable that they should better explain what is meant. It may be intended that all papers containing research should be presented to Section $G$ of the American Association, fearing that if the congress were not restricted Section G would be scantily patronized. This, however, does not seem a reasonable interpretation, for if there is a limitation on the congress, we should expect it to be open only to the best papers of most general interest, which could readily be decided by a committee on programme; lesser papers and papers of local interest being referred to Section $G$.

The claim cannot be made with justice that nomenclature has more than a factional interest. The majority of good botanists of the world pay no attention to nomenclature, and to them a discussion of its intricacies would be dry and worthless in the extreme. If such factional questions are to be the only ones con. sidered, the congress should not be called a "Botanical Congress," but a Nomenclature Congress. Whatever may be intended, it is an unfortunate use of words.

It is announced that a separate circular will shortly be distributed to botanists, giving further information. It is to be hoped that a clear explanation of this point will be given.

H. J. WEBBER.

Subtropical Laboratory, U. S. Department of Agriculture, Eustis, Fla,

\section{A Plea for a Fair Valuation of Experimental Physiology in Biological Courses.}

DURING the discussion of the biology question, one point has interested me more than any other, namels, that none of the parties who have taken part in the discussion hare keen able to avoid speaking at the same time of evolution and of natural selection. This thinking of biology, with constant reference to those two features of Darwinian teaching, has led me to beliere more strongly than ever that my view of the matter is not very much wrong. Howerer, an article in this journal, entitled "Biology in our Colleges: A Plea for a Broader and More Liberal Biology," induces me to take up my pen once more and explain matters a little more closely.

The tendency of the above-named paper "is - a plea for s5stematic biology," but it is marked by such a number of wonderful views on the different lines of physiological investigation that many specialists will really $t e$ at a loss about what they shall think. "Ssstematic zoölogy has gone, or, if still tolerated in a few colleges, is restricted to a rery subordinate position." I imagine that the biologist would not know what to do if systematic work, both zoölogical and botanical - the latter holds still, says the article, "an honored place in many universities, though evidently on the wane" - was not carried on, so that we could know how to lay our bands upon the different forms for further study. But the methods of such a work may be wrong, ind, fatally, of ten are so, namely, when it presents itself merely as simple regristation work, which strikingly has been called museum zoölogy or botany. Systematic work of any kind is to be valued just as much as morphological or physiological wo: $\mathbf{k}$, and so, eren if it is done still - as in fact it is in ninet5-nine cases out of a bundred - after the old Linnæan principles. On the other hand, a biological classification, or eren only a morphological classification, which employs biological characters of the forms, is to be more highly valued.

There is no doubt but that any naturalist enjoys the "delight 
n contemplating the aspects of nature," and "derives enjoyment from studying the forms, habits, and relationships of animals and plants," but how can he do so, and thus become a "biologist," unless he peers "through the tube of a compound microscope," etc., and does his proper hardening, and staining, and "monographs the same bit of tissue." How such investigations can "obscure the objects" we are trying to explain is rather a mystery. If, at least, anybody allows them to obscure our general views, there can be no speaking of scientific work. Natural history has become, in our century, so broad that no man possibly can become a "general naturalist" or a good "faunal naturalist" any more; he will, at least, not be able to treat all the questions that arise in any other way but in that of the amateur. The objects of our investigations lie a little deeper than to glance at all that is "most beantiful" and attractive to the eye.

How the article comes to the conclusion that the study of the minute structure is histology or that of development embryology, is rather doubtful. Further, I am anxious to know if any of the readers walking over the scientific border-land commanded by the naturalist who might be educated according to the principles given in the article of which we speak did ever meet with "the various pathogenic micrococci of fermentation and disease" which are mentioned (p. 353). However, I shall not enter upon further details, but turn towards the riew expressed in the said article about "section-cutters and physiologists," and I shall try to show that the work done by the workers in this particular field is far from being one-sided, at least, when we are speaking of real scientific men who put an equally fair valuation on all of the branches of their science. There are, as Professor E L. Greene sa:d, "a good many men try ing to figure somewhere" as scientific writers; but where are the scientific men to be found when we look towards the "scientific border-land" (Greene)? Therefore, we shall see that the right sort of scientific physiologists do not dare to depreciate any of the branches of their science.

Professor P. L. Panum once said that he who would not acknowledge physiology as the fundament of pathology and of the other departments of medical science has no right to be called a scientist. The vegetable physiologist who does not know anything about the principles of agriculture, $h$ orticulture, and forestry also lcses this right, and so he does, if he is ignorant with regard to a great deal of the practical, industrial branches. If we go to the opposite side, he must know how to carry out more minute investigations; he cannot aroid being something of a "slicecutter," and if he should be unfortunate enough to find "some new form of cell or new property of protoplasm," he must understand how to trace such a discovery as far as it can be traced. I am, the refore, very much surprised to hear that "the modern school of histologists, under the head of biology, teach little besides the minute structure and function of tissues." For my personal account, I have studied physiology almost from the time when I could appreciate the blessings of the study of natural history, but I have never met a man who claimed to be a physiologist, - in cas $u$ regetable physiologist,- and who, speaking, for example, of the nitrogen question, did not know the theoretical investigations quite as well as the practical experiments with fertilizers. But it must be noted that natural science has, at present, reached such an extent that no man possibly can cover the whole ground. Thus we have, with regard to special work, to become specialists, and, therefore, it is possible to take a farmer's boy and make out of him "a general natura!ist of the present day" or a "local faunal" - or floral - "naturalist." He will be no scientific man.

"B:ological" teaching is a failure for other reasons than those presente $l$ in the article. A cullege professor may offer a course in "general biology" and include "cell structure and the structure of the less complex tissues of animals and plants." But this is not "general biology;" the structure of two different forms has not the least to do with biology, it comes under the heading of internal or external morphology, and, when making a study of this kind, the student does not see more of life in general and of the laws by which it is governed than he saw before. Here the experimental physiology of animals and plants must be held up before a school of "biologists" who are following a phantom of their own imagination if they realls believe that function can be explained out of form. It is here that "the pendulum has swung too far," and it is not in the direction of "exclusire microscopic and physiologic work." The latter is safe enough. The fault lies entirels in the methods of modern biology, which begins with giring itself a wrong definition. If the modern biologist had cared more for experimental physiology, he would know now how to direct his a tions when the pendulum "swings back."

If I understand the article aright, the student should begin his biological work with elementary "general biology." He will, then, come to the university without, practically speaking, knowing anything about "biological" questions, and he will plunge into the study of cell-structure at once. This beginning of a course would be ansthing but beneficial to the young, ignorant student. If we take the example of the farmer's boy, he would naturally have to start with the study of what we call external morphology, collect plants, insects, or shells, and perhaps study their ways. It would be entirely lost on him to train him in the study of the cell and its organs. The other special sides of biology which are proposed for study are: 2. Morphology, taxonomy, and relationships; 3 . systematic work in widely-separated groups; 4. faunal work; 5 . the distribution of life in time and space; 6 . the principles and philosophy of biology.

These are the constituents of "biology!"

If it were so, the condition of natural science would be very lamentable. Not a single word or hint is given about the existence of experimental work, which should be the main factor in the whole course of training. It is true, as has been said, that "sham" is a hard expression, but here it might be used very properly. Many of the "biologists" of the present day will hardly understood my view, because they have been taught to regard the studiy of morphology as the essential part of their biological studies, but the physiologists will do so, because they know that we can take but very few steps in any direction without experiment. So long as biological courses do not include a proper course in experimental physiology of animals and plants, they cannot be called properly scientific. Anybody who will not believe this may be referred to Paul Bert's "La Science Experimen. tale."

There is no danger that I should have misunderstood the article. I see clearly that it wishes the "systematic biology," which might have been called, more logically, biological classification, to take a place a little more ahead of what it holds at present. But, trying to give a fair valuation of the other branches of physiology, it fails entirely. It is well known how language can command the thoughts, and if biologists go forth without knowing what they are teaching, the present confusion will grow instead of being settled. Perhaps "biology" will gain more and more lovers and become (as it is) rery fashionable, but the amount of restless work, chasing new problems and pursuing all that is interesting merely because it is new, will not, in time, be very much ralued. Nothing can save 'biology' except experimental phy siology.

J. Christian Bay.

Missouri Botanical Garden, July 7.

\section{Mr. McGee and the Washington Symposium}

It strikes me as curious, and certainly contrary to scientific usage, that the succinct statements made by $\mathrm{Mr}$. King as to the limitations of his inferences on the earth's age are ignored by our Washington friends. One might actually imagine that we were not on the scent of polymerism ${ }^{1}$ considered either with reference to its volume or the inseparable thermal effect; or that we were unaware of the high pressure and long range thermal variations of the physical constants of rocks. It takes so little time, so little cerebration to adduce critical commonplaces of this nature,

1 If there was one subject in which we imagined that our work had reached the point of prolixity, it was the change of chemical or molecular constitution as resulting from temperature and stress. ( f. Am. Journ., xxxili., p. 28, 1887; ibi ?., xxxvii., pp. 339, 351, 1889; ibld., xli1., p. 498, 1891; ibid.,

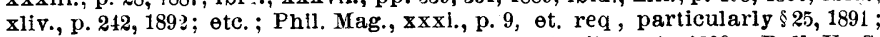
ibid., $\mathbf{x \times 8}$, p. $174, \S 3,1893 ;$ Am. Chem. Journal, $\times 11$, p 1, 1890; Bull. U. S. Geolog. Survey, No. 94, 189 ; ; and elsewhere). And now comes Mr. M:Ge日 Geolog. Survey, No. 94, 189 ?; and els $\in$ where). And now comes Mr. MuGee
with obviously well-meant instruction on the feaslbility of our po:ymeric with obviousl
mechanism. 